TRAD - Türkiye Rusya Araştırmaları Dergisi 4 (Kış 2020)

TJORS - Turkish Journal of Russian Studies 4 (Winter 2020)

$\begin{array}{lll}\text { Başlık } & : & \text { Viking Şehri Birka ve Hâkānü Rûs } \\ \text { Title } & : & \text { Birka the Viking City and the Нāqān of Rūs } \\ \text { Заголовок } & : & \text { Бирка, город викингов, и Хакан Русов }\end{array}$

Yazarlar / Authors / Автор

ORCID ID

Erman ŞAN

$\underline{0000-0001-8676-6215}$

Bu makaleye atıf için

To cite this article

Ссыдка на статью

DOI

Erman Şan, Viking Şehri Birka ve Hâkānü Rûs, Türkiye Rusya : $\quad$ Araştırmalar Dergisi 4 (2020): 1-19.

: $10.48068 / \operatorname{trad} .822433$

Makale Türü : Araştırma Makalesi

Type of Article : Research Article

Тип статьи : : Научно-исследовательская статья

Geliş Tarihi / Received / Поступила 인 06.11 .2020

Kabul Tarihi / Accepted / Принята к публикации : 28.12 .2020

Yayın Tarihi / Published / Опубликована : 31.12 .2020 


\section{Viking Şehri Birka ve Hâkānü R̂̂ิs*}

Öz: İbn Rüste'nin (ö. 301/913 sonrası) el-A'lâku'n-nefîse'sinde Rusların hükümdarlarından Hâkānü Rûs (خاقان رُوس) şeklinde bahsedilir. Bu ifadenin tam olarak karşılığı "Rus Hakanı" veya "Rus Kağanı"dır. Bunu destekleyen ve hatta tamamen aynı manaya gelen bir diğer ifadeyse, IX. yüzyılda Latince kaleme alınmış olan Annales Bertiniani isimli anonim kronikte bulunur. Burada 839 yılı olayları aktarılırken, Doğu Roma İmparatoru Theophilus'a (829-842) elçilerini göndermiş olan kuzeyli bir hükümdardan da Rhos chacanus yani "Rus Hakanı" veya "Rus Kağanı" şeklinde bahsedilir. Bu noktadan itibaren konuya dair asıl mesele, şayet hâkān ve chacanus birer özel isim değil de unvansa, söz konusu Rhos veya Rûs yöneticisinin Avrasya bozkırlarına ve bilhassa

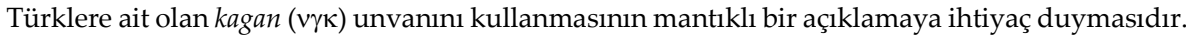
Konu hakkında hâlâ tam bir mutabakat sağlanamamış olmasına rağmen, Erken Rus tarihinin en önemli yazılı kaynakları olma özelliğine sahip Ortaçağ İslâm tarih ve coğrafya literatüründe bulunan başkaca bilgiler söz konusu karışıklığa açıklık kazandırma noktasında önemli bir rol oynar. Bu kaynaklardaki bilgiler de göz önünde bulundurulduğunda, söz konusu Hâkānü R̂̂s'un İsveç'teki Björkö adasında bulunan ve Viking Çağı'nın ilk şehri olan Birka'nın yöneticisi olduğu kanaatinin ağır bastığı söylenebilir. Zaten araştırmacıların vurguladıkları gibi, İslâm kaynaklarında Rûs denilmekle kastedilenler de tam olarak Birka'nın da dâhil olduğu bölgenin İskandinavları idiler. VIII. yüzyıldaki kuruluşunun ardından IX. yüzyıl ortalarından itibaren önemli bir siyasî ve ticarî merkez olarak parlayan Birka'nın krallar tarafından idare edildiğine dair IX. yüzyılda kaleme alınmış Vita Anskarii' de de güçlü emareler vardır. İşte bu krallar, güneye inen R̂ि tüccarlarının en önemli ticarî ortakları olan Hazarları aradan çıkarmaya çalışmış gibi gözükmektedirler. Çünkü kontrol ettikleri coğrafya nedeniyle Hazarlar, İskandinavya gibi kuzey memleketlerinin değerli ürünlerinin güneydeki İslâm ve Doğu Roma diyarlarına taşınması konusundaki en önemli aracılardı. Hatta Ortaçağ İslâm tarihçilerinin ve coğrafyacılarının da belirttiği gibi, Hazar Kağanlığı'nın gelirlerinin neredeyse tamamı, söz konusu ticarette oynadıkları aracılık sayesinde elde edilmekteydi. Bu aracılığa bir son vermek isteyen Birka yöneticileri ya da Hâkānü R̂ิs'u, Müslümanlar ve Doğu Roma nezdinde kendilerini, kağana sahip bir kağanlık olarak lanse etmiş olmalıdırlar.

Anahtar Kelimeler: Rus tarihi, Birka, R̂̂s, Vikingler, Hazar Kağanlığı, İbn Rüste, Doğu Roma İmparatorluğu, Abbâsîler.

\section{Birka the Viking City and the Hāqūn of Rīs}

\footnotetext{
Abstract: In Ibn Rusta's (d. after 301/913) work al-A'läk al-nafisa, the ruler of the Russians is described as Hāqān of Rūs (خاقان رُوس). The exact equivalent of this definition is the "Kagan of the

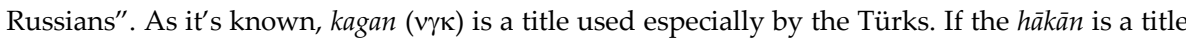
rather than a personal name, use this title of Russians ruler should explain in a logic manner. Considering other information found in Medieval Islamic written sources, we can say that Hāqān of $R \bar{u} s$ was the ruler of Birka in Sweden, the first city of the Viking Age. After its founding in the

* Dr. Öğr. Üyesi. Mimar Sinan Güzel Sanatlar Üniversitesi, Fen Edebiyat Fakültesi, Tarih Bölümü, E-mail: ermansan@gmail.com, ORCID ID: 0000-0001-8676-6215, DOI: 10.48068/trad.822433

** Bu makale, 12-14 Aralık 2020 tarihlerinde gerçekleştirilen 18. Uluslararası Türk Dünyası Sosyal Bilimler Kongresi'nde tarafımızca sunulan "Hâkānü Rûs'a Dair" başlıklı tebliğin geliştirilmiş hâlidir.
} 
$8^{\text {th }}$ century, the Viking city of Birka had flourished as an important political and commercial center from the mid-9 $9^{\text {th }}$ century. In Vita Anskarii, written in the $9^{\text {th }}$ century, there are strong indications that Birka was ruled by kings at that time. These kings seem to have tried to eliminate the Khazars, who were the most important trading partners of the Russian merchants who went South. Because of the geography they controlled, the Khazars were the most important intermediaries in transporting the valuable products of northern countries such as Scandinavia to the Islamic and Eastern Roman lands in the South. In fact, as stated by medieval Islamic historians and geographers, almost all of the income of the Khazar Khaganate was due to the intermediaries they undertook in the trade in question. Viking city of Birka rulers or Hāqān of Rūs who want to put an end to this intermediaries must have presented themselves as a khaganate, just like the Khazars, in the eyes of Muslims and Eastern Roman Empire.

Keywords: Russian history, Birka, Rūs, Vikings, Khazar Qaganate, Ibn Rusta, Eastern Roman Empire, 'Abbāsīds.

\section{Бирка, город викингов, и Хакан Русов}

Аннотация: В произведении Ибн Русте (ум. после 913 г.) "Китаб ал-а'лак ан-нафиса" ("Книга драгоценных ожерелий") русский правитель упоминается как Хакан Русов (خاق ان (رُوس (رُ) Точный эквивалент этого определения - "каган русских" иди “русский хан". Как известно, каган - титул, используемый в основном тюрками. Если хакан - это титул, а не личное имя, то его использование русскими правителями требует догического объяснения. Принимая во внимание другую информацию, найденную в средневековых исламских письменных источниках, мы можем сказать, что Хакан Русов был правителем Бирки в Швеции, первого города эпохи викингов. После своего основания в VIII веке Бирка достигает процветания как важный политический и торговый центр к середине 9 века. Указания в Vita Anskarii (“Житие святого Ансгария”), написанном в IX веке, дают веские основания полагать, что в то время Биркой правили короли. Похоже, они пытались уничтожить хазар, которые были важнейшими торговыми партнерами русов-купцов, ушедших на юг. Хазарский каганат в силу своего географического положения контродировал транспортировку ценных продуктов северных стран, таких как Скандинавия, в исламские и восточно-римские земли. Фактически, как утверждали средневековые исламские историки и географы, почти весь доход Хазарского каганата формировался за счет посредничества в этой торговле. Правители Бирки или Хаканы Русов, которые хотели положить этому конец, должны были, подобно хазарам, представлять себя каганатом в глазах мусульман и Восточной Римской империи.

Кдючевые слова: Русская история, Бирка, русы, викинги, Хазарский каганат, Ибн Русте, Восточная Римская империя, Аббасиды.

\section{Giriş: Hâkānü R̂̂s}

Erken dönem Rus tarihinin pek çok noktası, en başta kaynakların yetersizliği nedeniyle, henüz tam olarak aydınlatılamamış bir vaziyettedir. ${ }^{1}$

\footnotetext{
${ }^{1}$ Söz konusu belirsizlik ve bu konudaki tartı̧maların genel seyri için bkz. Peter B. Golden, "Rūs", EI2, VIII, 618-623; Omeljan Pritsak, "The Origin of Rus'”, Russian Review 36/3 (1947): 249-273; Akdes Nimet Kurat, Rusya Tarihi: Başlangıçtan 1917'ye Kadar (Ankara: TTK, 1999), XIX-XX; Fjodor
} 
Bununla birlikte araştırmacılarının çoğunun dikkatinden kaçmasına rağmen Ortaçağ İslâm tarih ve coğrafya eserlerinde Rusların söz konusu erken dönemine dair çok önemli bilgiler bulunmaktadır. ${ }^{2} \mathrm{Bu}$ bilgiler arasında hiç şüphesiz en ilginci, Ortaçağ Müslüman coğrafyacılarının en önemlilerinden İbn Rüste'nin (ö. 301/913 sonrası) el-A'lâku'n-nefîse ${ }^{3}$ isimli eserinde aktarılmıştır. İbn Rüste, er-Rûsiyye (الرُّوسية) başlığ1 altında Erken dönem Ruslarından bahsederken bunların yöneticilerinin kullandığı unvanı da zikreder: “Onların Hâkānü Rûs (خاقان رُوس) şeklinde adlandırllan bir melikleri vardır."4

İbn Rüste'nin kullandığı Hâkānü R̂̂s ifadesinin tam olarak karşılığ1 “Rus Hakanı" veya "Rus Kağanı"dır. Malum olduğu üzere, bilhassa Türklere ait olan kagan ( $v \gamma \kappa)$, esasında geniş Avrasya bozkırlarında kurulan en gelişmiş devlet teşekkülünün yöneticisine layık görülen bir unvandı. ${ }^{5}$ Yani Avrasya dâhilinde kullanılan kagan/hakan unvanını, yerleşik dünyanın şehînşâh veya augustus unvanlarının bozkırdaki karşılığı olarak düşünmek gerekir. Ne var ki Rusların bilinen ilk siyasî oluşumlarından itibaren yöneticileri için kullanmış oldukları unvanın aslında knez olması ${ }^{6}$, İbn Rüste'nin bir "Rus Kağanı"ndan bahsetmesi hadisesini ziyadesiyle ilginç kılar. Çünkü knez unvanı, kagan/hakan gibi daha cihanşümul bir unvanın yanında oldukça yerel ve bir o kadar da mütevazı kalır.

Eski Rusların böyle bir unvan kullanmalarını pek de olası görmeyen bazı araştırmacılar, İbn Rüste tarafından zikredilen hâkān'ın aslında kagan/hakan unvanı olmadığını düşünmelerine rağmen konu hakkında müstakil bir çalışması da bulunan Peter B. Golden gibi diğer bazı araştırmacılar ise, tam aksine el-A'lâku'n-nefisse'deki haberde kastedilenin gerçekten de Avrasya

\footnotetext{
Androshchuk, "Vikingler Doğuda", Viking Dünyası, ed. Stefan Brink - Neil Price, çev. Ebru Kılıç (İstanbul: Alfa Yayıncllık, 2015), 667-671.

2 Ortaçă̆ İslâm kaynaklarında R̂ि'lara dair haberler ve bunların değerlendirilmesi için bkz. Erman Şan, "Eski Ruslar ve Erken Tarihleri Bağlamında Köle İstihsâl Süreçleri Üzerine (IX.-X. Yüzylllar)", Tarihin Peşinde Bir Ömür Abdülkadir Özcan'a Armağan, ed. Hayrunnisa Alan - Ömer İşbilir - Zeynep Aycibin - Muhammet Ali Kılıç (İstanbul: Kronik, 2018), 711-735.

3 İbn Rüste ve çalışmasına dair son tespitler için bkz. Erman Şan, “İbn Rüste'nin el-A'lâku'nnefise' yi Ne Zaman Yazdığına Dair Yeni Tespitler", Belleten 83/296 (2019): 65-88.

4 İbn Rüste, el-A'lâku'n-nefise, 129. Hudûdü'l-'âlem'in (372/982-983) anonim yazarı ve Ebû Ubeyd el-Bekrî (ö. 487/1094) de aynı bilgiyi paylaşırlar. Bkz. Hudûdü'l-'âlem, 159; Ebû Ubeyd el-Bekrî, elMesâlik ve'l-memâlik, II, 58. Benzer diğer tanımlamalar Peter B. Golden tarafindan değerlendirmiştir. Bkz. “The Question of the Rus' Qağanate”, AEMAe 2 (1982): 82.

${ }^{5}$ Kagan unvanı hakkında bkz. Wolfram Eberhard, “Bir Kaç Eski Türk Ünvanı Hakkında”, Belleten 9/35 (1945): 319-340. Krş. için bkz. Peter B. Golden, Türk Halkları Tarihine Giriş, çev. Osman Karatay (İstanbul: Ötüken, 2017), 84-85.

${ }^{6}$ Bkz. Letopis Nestora, 10.
} 
bozkırlarının en yüksek yöneticisine ait olan kagan/hakan unvanı olduğu düşüncesindedirler. ${ }^{7}$

Bu noktadan itibaren konuya dair asıl mesele, şayet hâkān bir özel isim değil de bir unvansa, söz konusu Rûs yöneticisinin Avrasya bozkırlarına ve bilhassa Türklere ait olan kagan/hakan unvanını kullanmasının mantıklı bir açılamaya ihtiyaç duymasıdır. Viking Çağı'ndan itibaren Rusların erken tarihlerine biraz daha yakından incelersek böylesine karizmatik bir unvanı gerçekten de kullanıp kullanmadıklarını, kullandılarsa da bunun ne türden şartlar altında gerçekleşmiş olduğunu anlama imkânı bulabiliriz.

\section{Eski Ruslar: "Doğu'nun Vikingleri"}

Kuzey Germenlerinden ${ }^{8}$ bir grubun, sembolik başlangıcı Britannia'nın Northumbria sahilindeki Lindisfarne Manastırı'nın 793 yılındaki meşhur yağmalanması kabul edilen, VIII. yüzyıl sonundan XI. yüzyıl ortaları civarına kadar devam eden agresif yayılma dönemine "Viking Çağı" denilir. Elbette bu tanımlama, onların bilhassa batı yönündeki -yani Britannia, Hispania ve Gallia'ya- faaliyetleriyle alakadar olarak yapılır. ${ }^{9}$ Bu yayılmacıların doğudaki isimleriyse, muhataplarının kaynaklarına yansıdığı şekliyle çoğunlukla R̂िs'tur. Burada unutulmaması gereken ve çok önemli olan husus, “Doğu'nun Vikingleri" olan R̂ि'ların yani Eski Rusların İskandinav kimliklerini bir şekilde X. yüzyıla kadar muhafaza etmeyi başarmış olmalarıdır. Nihayetinde söz konusu R̂ि'lar; henüz Hıristiyanlaşmamış ve Slavlaşmamış aksine İskandinavya ile sıkı bağları bulunan topluluklardı. ${ }^{10}$

\footnotetext{
7 Konu hakkındaki görüşler ve bibliyografya için bkz. Golden, "The Question of the Rus' Qağanate", 82-83.

${ }^{8}$ Hint-Avrupalıların bir kolu olan ve Germenler diye adlandırılan halk kitleleri, MÖ 500'ler civarında -araştırmacılarca ilk Germen anayurdu olarak da betimlenen- Jastorf Kültürü dâhilinde ortaya çıkmış görünmektedirler. İlk Germen kültürü veya diğer bir deyişle ilk Germen toplulukları, MÖ II. yüzyıldan itibaren birbirlerinden ayrılmaya ve anavatanlarını terk etmeye başlarlar. Yüzyıllara yayılan bu ayrılış süreci neticesinde dil ve kültür açısından farklılaşmaların görüldüğü üç temel Germen grubu ortaya çıar: Doğu, Batı ve Kuzey Germenleri. Günümüzde İskandinav dillerinin dâhil olduğu grup olan ve MS VI. yüzyılda Batı Germenlerinden dilsel açıdan bariz biçimde ayrılan Kuzey Germenleri ise, anavatanları olarak tanımladığımız Jastorf ve muhtemelen komşuluğundaki Harpstedt kültürlerinin hâkim olduğu Ren ve Vistül nehirleri arasındaki bölgeyi en son terk eden veya hiç ayrılmayarak orada kalanlardır. Germenlere dair bu konular hakkında kısaca bkz. James P. Mallory, Hint-Avrupalıların İzinde: Dil, Arkeoloji ve Mit, çev. Müfit Günay (Ankara: Dost Kitabevi, 2002), 104-108; Michael P. Barnes, “Viking Çağında İskandinav Dilleri", Viking Dünyası, ed. Stefan Brink - Neil Price, çev. Ebru Kılıç (İstanbul: Alfa Yayıncilık, 2015), 343.

9 Özet bir şekilde bkz. Stefan Brink, “Vikingler Kimdi?", Viking Dünyası, ed. Stefan Brink - Neil Price, çev. Ebru Kılıç (İstanbul: Alfa Yayıncılık, 2015), 16-18.

${ }^{10}$ Bu konuya dair bkz. Brink, "Vikingler Kimdi?", 19-20.
} 
"Doğu'nun Vikingleri" diye tanımladığımız erken dönem Ruslarının ilk yayılma alanları Baltık'ın doğu yakasıydı. Araştırmacıların tespitlerine göre bu Eski Ruslar, henüz VIII. yüzyılda ve hatta daha da öncesinde Finlandiya Körfezi'nin hemen doğusunda bulunan Ladoga gölünün güneyinde yerleşmeye başlamışlardı. ${ }^{11}$ Elbette burada sözü edilenler isimleri belli olan tarihî şahsiyetler değildi; bu noktada en fazla maceracı İskandinav gruplardan söz edilebilir. Başlarında tarihî şahsiyetler bulunan Ruslara dair ilk haberler ise, ilk hanedanın kurucusu olan Rürik (ö. 870-879) ile ilgili olarak yazılı kaynaklara yansımaya başlar. Rürik'in faaliyetleri münasebetiyle adı geçen ilk şehirse Ladoga'dır. ${ }^{12}$ Burası büyük ihtimalle Rürik'in ilk ikametgâhı da olmuştu. Rürik liderliğindeki bu Ruslar, hemen sonrasında hâkimiyetlerini İlmen gölü civarına doğru genişletmişler; Povest Vremennıh Let'e göre de Rürik, 862'de Sloven şehri Novgorod'u ele geçirerek Rus Knezliği'ni kurmuştu. ${ }^{13}$

İbn Rüste'nin er-R̂िsiyye başlı̆g 1 altında aktardığ 1 ve Hâkānü Rûs'tan bahsettiği pasaj, Rürik'in söz konusu faaliyetlerinin en az çeyrek asır öncesine dair olmalıdır. Bu düşüncemizi destekleyen ve yine bir "Rus Kağanı"ndan bahsedilen başka bir haber ise, IX. yüzyılda Latince kaleme alınmış olan Annales Bertiniani isimli anonim kronikte bulunur. Burada 839 yılı olayları aktarılırken, Doğu Roma İmparatoru Theophilus'un (829-842) sarayına elçilerini göndermiş olan kuzeyli bir hükümdardan bahsedilir. Theophilus, Constantinopolis'e gidiş amaçları hakkında herhangi açık bir kayıt bulunmayan bu elçilik heyetini, ülkelerine dönme konusunda yardım ve kolaylık sağlanmasını rica ettiği bir mektupla Ingelheim'da bulunan Frank

\footnotetext{
11 Samuel H. Cross, "The Scandinavian Infiltration into Early Russia", Speculum 21/4 (1946): 505. Charlotte Hedenstierna-Jonson, bunu miladî VI. yüzyıla kadar geri çeker. Bkz. "Rus', Varangians and Birka Warriors", The Martial Society: Aspect of Warriors, Fortifications and Social Change in Scandinavia, ed. Lena Holmquist Olausson - Michael Olausson, (Stockholm: Archaeological Research Laboratory, Stockholm University, 2009), 159.

12 Tatjana N. Jackson, Staraya Ladoga (Eski Ladoga) olarak bilinen Aldeigjuborg' un 750'lerdeki ilk sakinlerinin İskandinavlar olduğunu; Slavların Ladoga'ya biraz sonrasında yani 760'larda geldiklerini düşünür. Bkz. "Aldeigjuborg of the Sagas in the Light of Archaeological Data", Á austrvega: Saga and East Scandinavia, I, ed. Agneta Ney - Henrik Williams - Fredrik C. Ljungqvist, (Gävle: Gävle University, 2009), 438-442.

${ }^{13}$ Letopis Nestora, 8-9. Söz konusu Novgorod şehri, araştırmacılarca Rürikovo Gorodişçe şeklinde adlandırılır ve bu şehrin kalıntıları İlmen gölü kuzeyinde, ona dökülen Volhov'un ağzına yakın konumda bir yerde bulunur. Nitekim Peter B. Golden, bildiğimiz Novgorod şehrinin aslında 930'larda kurulmuş olduğunu; bu haberde kastedilen şehrin ise Rürikovo Gorodişçe olması gerektiğini bilhassa vurgular. Bkz. "Rūs", 622. Charlotte Hedenstierna-Jonson da Rürikovo Gorodiş̧̧e'nin kuruluşunu IX. yüzyıl başlarına tarihler. Bkz. "Rus', Varangians and Birka Warriors", 160.
} 
Kralı Ludovicus Pius'a (814-840) yönlendirmiştir. ${ }^{14}$ Bu elçiliği ilginç kılan husus ise, Annales Bertiniani'deki kaydın devamında, Sueonia'dan yani İsveç civarından ${ }^{15}$ gelmiş olan bu Rhosların rexine yani kralına da chacanus denildiği bilgisinin bulunmasıdır: "Rhos... quos rex illorum chacanus." 16

Annales Bertiniani'de chacanus ifadesiyle kastedilenin de yine hakan yani kagan unvanı olup olmadığı konusunda tam bir mutabakat olduğu söylenemez. ${ }^{17}$ Açıkça görüleceği gibi, Annales Bertiniani'de aktarılanla elA'lâku'n-nefîse' de aktarılan bilgiler birbirlerinin aynısıdır. Elbette burada da bir benzerlikten veya karışıklıktan söz etmek mümkün olmasına rağmen Ortaçağ İslâm coğrafyacılarının bazıları tarafından aktarılan benzer mahiyetteki başkaca bilgileri de göz önünde bulundurduğumuzda hem Annales Bertiniani'deki Rhos chacanus ile hem de el-A'lâku'n-nefìse' de Hâkānü $R \hat{u s}$ ile kastedilenin gerçekten de bir "Rus Kağanı" veya "Rus Hakanı" olduğu düşünülebilir. ${ }^{18}$ Şu da var ki bu bilgi sadece $e l-A$ 'lâku'n-nefîse' de veya sadece Annales Bertiniani'de bulunmuş olsaydı, bunu kolayca bir karışıklığa yormak mümkün olabilirdi. Ne var ki hemen hemen aynı dönemlere ait olan hemen hemen aynı bilginin birbirlerinden haberdar olması imkânsız iki eserde birden bulunması, bir "Rus Kağanı"ndan bahsedilmesi hadisesinin Rûs'ların tasarladığı bir senaryonun parçasıymış gibi gözükmesine de neden olmaktadır.

Jonathan Shepard ve Mihail İ. Artamonov gibi bazı araştırmacılar, hükümdarları hakan veya kagan unvanı taşıyan Ruslar ile Hazarların doğrudan veya dolaylı bir bağlantısı bulunmuş olduğu kanısındadırlar; en basitinden söz konusu Ruslar Hazarların idarî şemasını kopyalamış

\footnotetext{
14 İşin aslına bakılırsa Theophilus'un bu dönemlerde uğraşması gereken çok daha büyük sorunları bulunuyordu. Bkz. Erman Şan, “Mu'tasım-Billâh'ın 223/838 Yılındaki Asia Minor Seferinin Hedefi: Küçük Constantinopolis", CEDRUS 8 (2020): 547-561.

15 Sueonia için bkz. Vilhelm Ludvig Peter Thomsen, The Relations between Ancient Russia and Scandinavia and The Origin of the Russian State, (Oxford - London: James Parker and Co., 1877), 4144.

16 Annales Bertiniani, 19-20. Anlatı ve Annales Bertiniani'de geçen tanımlamanın en güncel tartışması, yakında yayınlanacak olan çalışmasında Altay Tayfun Özcan tarafından yapılmıştır. Bkz. “Karolenj Sarayındaki Rus Elçilerinin Kağanı: Rus Kağanı mı Hazar Kağanı mı?” (yakında çıkacak). Henüz basılmamış olmasına rağmen faydalanmam için bu değerli çalışmasını bana gönderip kullanmama izin veren değerli ağabeyim Prof. Dr. Altay Tayfun Özcan'a bu vesileyle teşekkür ederim. Vilhelm Ludvig Peter Thomsen'in önemli tespitleri için bkz. The Relations between Ancient Russia and Scandinavia and The Origin of the Russian State, 37-43.

17 Altay Tayfun Özcan'ın çalışmasına ilaveten bkz. Ildar Garipzanov, “The Annals of St. Bertin (839) and Chacanus of the Rhos", Ruthenica 5 (2006): 7-11.

18 Altay Tayfun Özcan, bunun Hazar Kağanı şeklinde anlaşılması gerektiğini düşünür. Bkz. “Karolenj Sarayındaki Rus Elçilerinin Kağanı: Rus Kağanı mı Hazar Kağanı mı?” (yakında çıkacak).
} 
olmalıydılar. ${ }^{19} \mathrm{Bu}$ gayet makul bir çıkarımdır; çünkü miladî IX. yüzyılda Doğu Avrupa'da bir kağanlıktan bahsedilecekse, elbette burada ilk akla gelenler Hazarlar olacaktır. Her ne kadar Hazarlardan bir etkilenme veya bir yakıştırma söz konusu olabilirse de, İbn Rüste'nin bahsettiği Hâkānü Rûs'un veya onun temsilcilerinin bu unvanı kullanmalarının tamamen farklı bir gerekçesi varmış gibidir. En nihayetinde verilmek istenen mesaj kendilerinin de Hazarlar gibi olduklarıyken; asıl istedikleriyse kendilerine de tıpkı Hazarlar gibi ticaret yapma imkânı tanınmasıydı. Bu noktadan itibaren hükümdarları için kagan/hakan unvanını kullanan ve olasılıkla Hazarlarla bir şekilde bağlantısı bulunan Hâkānü Rûs'un kim olduğuna ilaveten şayet mevcut idiyse "Rus Kağanlığı" nın nerede bulunmuş olduğu gibi meselelerle karşı karşıya kalırız.

Yukarıda şayet bir "Rus Kağanı"ndan ve bir “Rus Kağanlığı"ndan söz edilecekse, bunun Hazarlarla veya hiç olmazsa Hazarların idarî yapılanmasıyla bir ilgisinin bulunduğunun düşünülmesinin oldukça doğal olduğunu belirtmiştik. Ne var ki Rusların erken tarihinin en önemli yazılı kaynakları olma özelliğine sahip Ortaçağ İslâm tarih ve coğrafya literatüründe bulunan başkaca bilgiler, bu konu özelindeki R̂ิs-Hazar bağlantısını daha başka bir şekilde yorumlama imkânı tanıdıkları gibi bir "Rus Kağanı"nın varlığı meselesine de açıklık getirecek türdendir.

\section{Hazarlar ve "Doğu'nun Vikingleri"}

Müslümanlar ile Hazarlar arasındaki münasebetler, Hazarların İslâm topraklarına 183/798-799 yılında gerçekleştirdikleri son seferlerine ${ }^{20}$ kadar pek de dostane değildi. ${ }^{21}$ Bu tarihten itibaren Hazarlar ile Abbâsîler arasında her iki tarafın da çıarına olan ticarî faaliyetler gözle görülür bir biçimde

\footnotetext{
${ }^{19}$ Jonathan Shepard, Rhos chacanus'un merkezinin yukarıda sözünü ettiğimiz Rürikovo Gorodiş̧̧e olduğunu ve Hazarlardan etkilenmeleri nedeniyle böyle bir unvan kullandıklarını belirtir. Bkz. "Viking Rus ve Bizans", Viking Dünyası, ed. Stefan Brink - Neil Price, çev. Ebru Kılıç (İstanbul: Alfa Yayıncılık, 2015), 626-627. Mihail İ. Artamonov ise, Hazarlardan bu unvanı alarak kendilerine uyarlayanların Kievli knezler olduklarını ve bu unvanı Hazarlardan bağımsızlıklarının bir göstergesi olarak kullandıklarını düşünür. Bkz. Hazar Tarihi: Türkler, Yahudiler ve Ruslar, çev. D. Ahsen Batur (İstanbul: Selenge Yayınları, 2004), 470. Ayrıca krş. için bkz. Douglas Morton Dunlop, Hazar Yahudi Tarihi, çev. Zahide Ay (İstanbul: Selenge Yayınları, 2008), 256.

${ }^{20}$ Hazarların gerçekleştirdikleri söz konusu son sefere dair bkz. Taberî, Târîhu'l-ümem ve'l-mülûk, VIII, 270; İbn Miskeveyh, Tecâribü'l-ümem ve te'âkibü'l-himem, III, 225-226.

${ }^{21}$ Müslümanlar ile Hazar Kağanlığı arasında mücadelelerin genel seyri hakkında bkz. Michael Kmosko, "Araplar ve Hazarlar", çev. A. Cemal Köprülü, TM 3 (1926-1933): 133-155; Dunlop, Hazar Yahudi Tarihi, 57-103, 193-200; Artamonov, Hazar Tarihi: Türkler, Yahudiler ve Ruslar, 269306; Peter B. Golden, Hazar Çalışmaları, çev. Egemen Ç. Mızrak (İstanbul: Selenge Yayınları, 2006), 73-79.
} 
artmıştı. İlaveten Hazarlar, İskandinavya gibi kuzey memleketlerinin değerli ürünlerinin güneydeki İslâm diyarlarına taşınması konusundaki en önemli aracılar hâline de gelmişlerdi. ${ }^{22}$ Hatta Ortaçağ İslâm tarihçilerinin ve coğrafyacılarının da belirttiği gibi, Hazar Kağanlığı' nın gelirlerinin neredeyse tamamı söz konusu ticarette oynadıkları aracılık sayesinde elde ettiklerinden oluşuyordu. Örneğin İbn Hurdâzbih (ö. 300/912-913), R̂̂s tüccarlarının İtil'e getirdikleri mallarından onda birini Hazar hükümdarına vergi olarak verdiklerini belirtir. ${ }^{23}$ İstahrî (ö. 340/951-952 sonrası) de çok benzer biçimde Hazar hükümdarının gelirinin en önemli kısmının; yolların gözetimine ilaveten tüm yollar, tüm denizler ve tüm nehirler üzerinden taşınan ticarî ürünlerden alınan vergilerden oluştuğunu ifade eder. ${ }^{24}$ İstahrî̀nin, Hazarların ticaretinin doğasına dair başka bilgiler de aktarmasına rağmen konumuz özelinde vurguladığı en önemli husus, Hazar ülkesinden İslâm diyarlarına taşınan ticarî eşyaların, aslında Hazarlara da başka memleketlerden getirildiğini belirtmesidir. ${ }^{25} \mathrm{Ne}$ var ki bu aracılığı sadece İslâm memleketleri için değil aynı zamanda Doğu Roma İmparatorluğu için de ifa etmekteydiler. ${ }^{26}$ Yani, Omeljan Pritsak'ın deyimiyle ifade etmek gerekirse, Hazarların yaptıkları aslında "yeniden ihracat"tan fazlası değildi. ${ }^{27}$

\section{Birka'nın Hâkānü R̂ิs'u}

Miladî VIII. yüzyıl sonunda gerçekleşen Hazar-Abbâsî barışının ardından bir ticarî çekim merkezi hâline gelen Hazar memleketine ${ }^{28}$ ürünlerini getirenler arasında İbn Rüste'nin meliklerine hâkān denildiğini belirttiği Rûs'ların da bulunması çok önemlidir. İlaveten pasajdan anlaşıldığı kadarıyla bunların memleketi gerçekten de İskandinavya idi:29

\footnotetext{
22 Ele aldığımız dönemde Hazarların uluslararası ticarette oynadıkları aracılık rolüne ve bunun aktörlerine dair bkz. Ali Ahmetbeyoğlu, "Avrupa Hun ve Hazar Devletlerinin İktisadî Gelir Kaynakları", Belleten 69/254 (2005): 123-126; Ulaş Töre Sivrioğlu, "8-11. Yüzyıllarda Müslüman Viking Ticareti ve Kuzey Avrupa'da Bulunan İslâm Dirhemleri", Arkeoloji ve Sanat 155 (2017): 202. Egil Mikkelsen'e göre de, sikke akışı miladî VIII. yüzyıl sonunda başlayıp en geniş hacmine de X. yüzyılda ulaşmıştır. Bkz. “Vikingler ve İslam”, Viking Dünyası, ed. Stefan Brink - Neil Price, çev. Ebru Kılıç (İstanbul: Alfa Yayıncıllk, 2015), 688.

23 İbn Hurdâzbih, Kitâbü'l-Mesâlik ve'l-memâlik, 154.

24 İstahrî, Kitâbü'l-Mesâlik ve'l-memâlik, 221.

25 İstahrî, Kitâbü'l-Mesâlik ve'l-memâlik, 223-224.

${ }^{26}$ Bkz. Shepard, "Viking Rus ve Bizans", 626-627.

${ }^{27}$ Omeljan Pritsak, "Türk-Slav Ortak Yaşamı: Güneydoğu Avrupa'nın Türk Göçebeleri”, çev. Osman Karatay, Türkler, II, ed. Hasan Celal Güzel - Kemal Çiçek - Salim Koca (Ankara: Yeni Türkiye Yayınları, 2002), 517.

28 İbrahim Kafesoğlu, bu bağlamda Hazar memleketinin oynadığı rolü Pax Hazarica (Hazar Barışı) olarak tanımlamıştır. Bkz. Türk Millî Kültürü, (İstanbul: Ötüken Neşriyat, 2007), 172.

29 İbn Rüste, el-A'lâku'n-nefise, 129.
} 
“R̂̂s memleketine (er-Rûsiyye) (الرُوسية) gelince... Oras1 [er-R̂̂siyye] etrafı denizle çevrili bir adadadır. Onların [R̂ि'ların] oturdukları bu ada, ormanlıklar ve ağaçlıklar arasından üç günlük yol mesafesi [genişliği]ndedir... Onların [Rûs'ların] Hâkānü Rûs (خاقان رُوس) şeklinde adlandırılan bir melikleri vardır. Ve onlar [R̂ิs'lar], Sakālibe $0^{30}$ ye hücum ederler. Onların [Sakālibe'nin] yanında karaya çıkana kadar gemilerle giderler ve onları [Sakālibe'yi] esir ederek Hazarân'a [İtil şehrine] ve Bulkâr'a [Bulgar şehrine] satmak için götürürler..."

İbn Rüste'nin tarifinin oldukça muğlâkmış gibi gözükmesine rağmen, söz konusu dönem İskandinavya'sında bu tarife uygun sadece tek bir şehrin bulunması işimizi oldukça kolaylaştırır. Söz konusu şehir de, Viking Çağı'nın ilk şehri3 ${ }^{31}$ olarak VIII. yüzyıl ortalarında kurulmuş olan Birka'ydı.

Birka, tıpkı İbn Rüste'nin pasajındaki gibi bir ada olan Björkö üzerinde kuruluydu. Zaten Erken Viking Çağı'nın dört şehri arasında Birka haricindekiler bir ada üzerinde konumlanmış da değildi. Söz konusu dört şehir arasında yine sadece Birka İsveç'te yani Sueonia' da bulunur ${ }^{32}$ ki, İslâm coğrafya literatürünün önde gelen uzmanlarından Ramazan Şeşen'in ve Viking Çağı uzmanlarından Stefan Brink'in de belirttikleri gibi, burası Ortaçağ İslâm kaynaklarında Vikinglerin yani $R \hat{u} s^{\prime} l a r ı n$ memleketi olarak tanımlanır. ${ }^{33}$

Gerçekten de bu iki araştırmacının belirttiği gibi, Ortaçağ'ın diğer Müslüman coğrafyacılarının miladî IX. ve $X$. yüzyıllara dair haberlerinde R̂िs'ların memleketi olarak tarif ettikleri yer de tam olarak İskandinavya'ydı. Örneğin, İbn Hurdâzbih'in tarifini verdiği Rûs (الرُّوس) tüccarlarının güney yönünde takip ettikleri güzergâhla ilgili pasaj, İbn Rüste'nin yukarıdaki pasajıyla birlikte değerlendirildiğinde -ki hemen hemen aynı dönemden bahsederler- "Doğu'nun Vikingleri" şeklinde tanımladığımız R̂िs'ların güneye inişlerinde hangi yolları kullandıkları konusuna açıklık getirir:34

\footnotetext{
${ }^{30}$ Burada gözden kaçırılmaması gereken en önemli husus, Sakālibe' nin düşünülenin aksine sadece Slavları kastetmediği; aynı zamanda Doğu Avrupa ve İskandinavya'nın Slav dışı halklarını da kapsayan genel bir tanımlama olduğudur. Bu konuya dair bkz. Erman Şan, "Besiûs el-Melik ve Sakälibe' nin Hıristiyan Olması (Basileus Symeon ve Tuna Bulgaryası'nın Hıristiyanlaşması)", TDA 114/224 (2016): 201-203.

${ }^{31}$ Dagfinn Skre, "İskandinavya'da Kentleşmenin Gelişmesi”, Viking Dünyası, ed. Stefan Brink Neil Price, çev. Ebru Kılıç (İstanbul: Alfa Yayıncllık, 2015), 112.

32 VIII. yüzyıl ortalarında kurulan Birka İsveç'te; 790'larda kurulan Kaupang Norveç'te; yine 790'larda kurulan Ribe ve $808^{\prime}$ de kurulan Hedeby ise Danimarka'dadır. Bu şehirlerin kuruluşlarına dair bkz. Skre, "İskandinavya'da Kentleşmenin Gelişmesi”, 112-113.

${ }^{33}$ Ramazan Şeşen, İslâm Coğrafyacılarına Göre Türkler ve Türk Ülkeleri, (Ankara: TTK, 2001), 39, dn. 70; Brink, "Vikingler Kimdi?", 16.

34 İbn Hurdâzbih, Kitâbü'l-Mesâlik ve'l-memâlik, 154.
} 
“R̂ิs (الرُوس) tüccarlarının güzergâhına gelince... Onlar [R̂ि'lar], Sakälibe'nin bir koludur ve hazz derilerini, siyah tilki derilerini ve kılıçları, en uzaktaki Saklebe'den Bahrü'r-Rûm $\hat{\imath}^{\prime}$ ye [Karadeniz ${ }^{35}$ ] götürmektedirler. Sâhibü'r-Rûm'a [Doğu Roma imparatoruna] onda bir verirler. Eğer Sakälibe'nin nehri Tinîs'ten [Don'dan] giderlerse Hazar şehri Hamlîc'e uğrarlar ve oranın sâhibine [hükümdarına da] onda bir verirler. Sonra Bahrü Cürcân'a [Hazar denizine] varırlar ve istedikleri herhangi bir sahile çıarlar. Bu deniz [Hazar denizi ise] 500 fersah genişliğindedir. [Rûs'lar] Bazen ticarî mallarını Cürcân'dan [Cürcân eyaletinden] develer üzerinde Bağdâd'a götürürler. ${ }^{36}$ Yanlarındaki Sakälibe hizmetçileri [de onlar için] tercüme yaparlar. Bunlar [tercümanlık yapan Sakālibe hizmetçileri], onların [Rûs'ların] Hıristiyan olduklarını ileri sürerler ve onlar da [R̂ि' lar] cizye öderler..." ${ }^{\prime 37}$

Pasajda ilk dikkati çeken husus, değerli hayvan kürklerinin Karadeniz civarına taşınmasında bizim Birkalı olarak teşhis ettiğimiz R̂ि'ların tüccarlarının oynadığı roldür. Birka'da yapılan arkeolojik kazılarda, miladîX. yüzyıla tarihlenen çok miktarda söz konusu değerli kürke sahip hayvan kemiğine rastlanmıştır. Bu nedenle araştırmacılar, kurulduğu andan itibaren Birka şehri için kürk ticaretinin -tıpkı İbn Hurdâzbih'in pasajında da betimlendiği gibi- çok önemli olduğunu düşünürler..$^{38}$

Konumuz özelinde önemli olan bir diğer husus da, İbn Hurdâzbih tarafından tarifi yapılan bu güzergâhın çok büyük ihtimalle eserine ilk şeklini verdiği dönem olan miladî IX. yüzyıl ortalarına dair durumu betimlemesidir. ${ }^{39}$ Björn Ambrosiani ve Egil Mikkelsen de bu düşüncededirler

\footnotetext{
${ }^{35}$ Bahrü' $r$-R̂̂mî yani "Roma Denizi" ile kastedilenin Akdeniz değil de Karadeniz olmasına dair bkz. Semen Rapoport, "Mohemmedan Writers on Slavs and Russians", SEER 8/22 (1929): 81.

${ }^{36}$ Guy F. Isitt, Basra Körfezi'ndeki bazı batıkların İskandinavlara ait olduğunu ve İskandinav yani Rûs tüccarlarının gerçekten de bu derece güneye inmiş olduklarını düşünür. Bkz. "Vikings in the Persian Gulf", JRAS 17/4 (2007): 389-406.

${ }^{37}$ Haberde R $u s^{\prime}$ ların Hıristiyan oldukları ifade edilmesinden sonra kendilerinden cizye alınması, bunların ticareten zimmî olarak kabul edildiğini gösterebilir. Böylelikle de harb̂̂ tüccarların ödemek zorunda oldukları onda bir yerine yirmide bir ödemiş olmalıdırlar. Buna dair bkz. Ebû Yûsuf, Kitâbü'l-Harâc, 215 vd. Nihayetinde ticaretlerini daha da kârlı bir hâle getiren bir durum söz konusudur.

${ }^{38}$ Björn Ambrosiani, "Birka and Scandinavia's Trade with the East", Russian History 32/3-4 (2005): 288.

39 Peter B. Golden, İbn Hurdâzbih'in eserinde aktarılan başkaca bilgileri de analiz ederek söz konusu haberin muhtemelen miladî 840 yılına ait olduğunu tespit etmiştir. Bkz. "The Question of the Rus' Qağanate", 83. James E. Montgomery de bunun Arapça kaynaklardaki Rûs'a dair ilk betimleme olduğunu vurgular. Bkz. "Arapça Kaynaklarda Vikingler", Viking Dünyası, ed. Stefan Brink - Neil Price, çev. Ebru Kılıç (İstanbul: Alfa Yayıncılık, 2015), 695. İbn Hurdâzbih'in eserini kaleme alışına dair bkz. İgnatiy Yulianoviç Kraçkovskiy, Arabskaya Geografiçeskaya Literatura,
} 
ki, Viking Çağı uzmanlarının da söz konusu bilgileri miladî IX. yüzyıl ortasına ait kabul etmeleri ${ }^{40}$ çok önemlidir. Yani kabaca İbn Rüste'nin bahsettiği Hâkānü R̂̂s ile faaliyetlerini tespit edebildiğimiz ilk knez Rürik arasında, kabaca 840-860 yılları arası, bir dönem söz konusudur. Hem söz konusu güzergâh üzerinde hem de İskandinavya'da gün yüzüne çıarılmış Müslüman dirhemleri de İbn Hurdazbih'in verdiği rotanın söz konusu tarihteki işlerliğini teyit eder. ${ }^{41}$ Anlaşıldığ 1 kadarıyla bu ticaret $R \hat{u} s^{\prime} l a r$ açısından oldukça kârlıydı. Belki de Hazarlar gibi aracılar olmasaydı daha da kârlı olabilirdi. VIII. yüzyıl ortalarında Birka'nın yöneticileri de kendilerine bu soruyu sormuş olmalılar ki birbirine yakın tarihli iki haberde, yani elA'lâku'n-nefisse'nin ve Annales Bertiniani'nin haberlerinde, bu girişimin yansımalarını görebiliyoruz.

Büyük ihtimalle güneydeki büyük ekonomiler olan Doğu Roma'ya ve Abbâsîlere, Hazarların yeniden ihracatı yerine kendilerinin doğrudan ihracatı teklifini götürmüşlerdi. Amaçları da bilhassa Hazarları saf dışı bırakmak ve daha fazla gümüş elde etmek olarak düşünülebilir. ${ }^{42} \mathrm{Bu}$ R̂ิs tüccarları veya elçileri de bilhassa Müslümanlar ve Doğu Roma İmparatorluğu nezdinde kendilerini tanıtmanın en kestirme yolu olarak, tıpkı Hazarlar gibi kağana sahip bir kağanlık olduklarını belirtmiş olmalıdırlar. Aynı zamanda Birka'nın, İtil ve Bulgar şehirlerinin daha kuzeyindeki bir benzeri olduğu vurgusu da yapılmak istenmiş gibidir. $O$ halde, gerçekten de söz konusu dönem aralığında Birka ile ilgisi bulunan bir Hâkānü R̂̂s'tan yani bir kraldan söz etmek mümkün müydü?

865 yılındaki ölümüne değin misyonerlik faaliyetleri için 829-830 ve 851852 yıllarında Birka'da bulunan Anskar'ın hayatının anlatıldı̆̆ı Vita Anskarii' $\mathrm{de}^{43}$ (yakl. 870); Birka'ya ilk gidişinde Biörn isimli, ikinci gidişinde de Olef isimli krallardan bahsedilmiş olması çok önemlidir. ${ }^{44}$ Yukarıda isimlerini

\footnotetext{
(Moskva - Leningrad: İzdatelstvo Akademii Nauk SSSR, 1957), 148; Ramazan Şeşen, Müslümanlarda Tarih-Coğrafya Yazıcılı̆̆ı, (İstanbul: İSAR Vakfı Yayınları, 2016), 141; Sayyid Maqbul Ahmad, "İbn Hurdâzbih", DİA, XX, 79.

${ }^{40}$ Mikkelsen, "Vikingler ve İslam", 685; Ambrosiani, "Birka and Scandinavia's Trade with the East", 290

41 İbn Hurdâzbih'in tarifini verdiği yolun bilhassa Müslümanlara ait dirhem buluntuları üzerinden yorumlanması için bkz. Roman K. Kovalev - Alexis C. Kaelin, "Circulation of Arab Silver in Medieval Afro-Eurasia", History Compass 5/2 (2007): 568-569.

${ }^{42}$ Vikingler ve İslâm sikkeleri hakkında bkz. Sivrioğlu, "8-11. Yüzyıllarda Müslüman - Viking Ticareti ve Kuzey Avrupa'da Bulunan İslâm Dirhemleri", 197-208.

43 Anskar ve Vita Anskarii için bkz. Stefan Brink, "İskandinavya'nın Hıristiyanlaşması ve İlk Kiliselerin Doğuşu", Viking Dünyası, ed. Stefan Brink - Neil Price, çev. Ebru Kılıç (İstanbul: Alfa Yayıncilık, 2015), 780-781.

${ }^{44}$ Bkz. Rimbert, Vita Anskarii, 45, 48-49, 89-100.
} 
zikrettiğimiz Erken Viking Çağı şehirlerinin (Birka, Kaupang, Ribe ve Hedeby) kuruluşu ve gelişimi üzerine önemli tespitlerde bulunduğu çalışmasında Dagfinn Skre de, söz konusu şehirlerin krallar veya küçük krallar tarafından kurulmuş olduğunun altını çizer. ${ }^{45}$ Birka özelinde bunun göstergesi olarak da, Birka'nın üzerinde bulunduğu Björkö adasının komşuluğundaki Adelsö'da bir kraliyet ikametgâhı olduğu kabul edilen Alsnö hus'un kalıntıları gün yüzüne çıkarılmıştır. ${ }^{46} \mathrm{Bu}$ yapının inşa tarihiyle İbn Rüste'nin pasajında bahsettiği tarihlerin zamansal olarak uyumlu olması, Hâkānü Rûs'un gerçekten de Birka ile bir bağlantısı olduğu görüşünü kuvvetlendirir. ${ }^{47}$

Vita Anskarii' de tam olarak ele aldığımız döneme dair bir betimlemede de Birka'nın zengin tüccarlarla, pek çok emtia ve parayla dolu bir şehir olduğu belirtilir. ${ }^{48} \mathrm{Bu}$ zengin şehrin doğuyla bilhassa Müslümanlarla ticaretine ve hatta Müslümanların burada bulunmuş olabileceğine dair olarak da yalnızca dirhemlerden oluşmayan çokça arkeolojik buluntu da ele geçirilmiştir. ${ }^{49}$

Birkalı Rûs'lar, doğrudan ticarî bağlantılar kurmak ve Hazarları aradan çıkarmak amacıyla güneydeki ilk girişimlerinden olumlu netice alamamış olmalılar ki güzergâhları üzerinde bulunan ${ }^{50}$ ve o dönemlerde Hazarlara bağlı olduğu anlaşılan Kiev'i ${ }^{51}$ ele geçirmeye karar vermişlerdi. ${ }^{52}$ Mes'ûdî (ö. 345/956) ise, Kiev'deki R̂̂s hâkimiyetini şöyle bir haberle aktarır: "Sakālibe

\footnotetext{
${ }^{45}$ Skre, "İskandinavya' da Kentleşmenin Gelişmesi”, 116.

46 Björn Ambrosiani, "Birka", Viking Dünyası, ed. Stefan Brink - Neil Price, çev. Ebru Kılıç (İstanbul: Alfa Yayıncilık, 2015), 125.

47 Zaten 970'ler gibi Birka, biraz daha kuzeyinde kurulan Sigtuna'nın gelişmesiyle önemini yitirecek ve terk edilecektir. Bkz. Jonas Ros, "Sigtuna", Viking Dünyası, ed. Stefan Brink - Neil Price, çev. Ebru Kılıç (İstanbul: Alfa Yayıncılık, 2015), 178. Bununla birlikte Birka, zenginliğinin başlıca temeli gibi gözüken güneyle ticareti de Gotland'a kaptırmış gibidir. Bkz. Ambrosiani, "Birka and Scandinavia's Trade with the East", 292.

48 Rimbert, Vita Anskarii, 65.

${ }^{49}$ Bruno Kisch, "Weights and Scales in Mediaeval Scandinavia: A New Proof of Arabic Influence on Northern Europe in Viking Times", JHMAS 14/2 (1959): 162, 164, 166; Mikkelsen, "Vikingler ve İslam", 691. Björn Ambrosiani, söz konusu bağlantının Staraya Ladoga ve Rürikovo Gorodişçe üzerinden kurulduğunu düşünür. Bkz. "Birka and Scandinavia's Trade with the East", 289.

50 İbn Hurdâzbih'ten yukarıda aktardığımız güzergâhta zikredilmemesine rağmen Kiev şehri, Povest Vremenmih Let'teki tarife nazaran Doğu Roma'ya doğru giden yolun üzerindeki önemli bir noktaydı. Bkz. Shepard, "Viking Rus ve Bizans", 629 vd. Güzergâha dair bkz. Letopis Nestora, 2; Kurat, Rusya Tarihi, 15.

${ }^{51}$ Julius Brutzkus, makalesinin isminden anlaşılacağı gibi Kiev şehrinin "Doğu'nun Vikingleri" diye tanımladığımız R̂ิs'lar tarafından hâkimiyet altına alınmasından evvel Hazar Kağanlığı'nın bir şehri olduğunu ifade eder. Kiev'in kökenlerine, kuruluşuna ve önemine dair bkz. "The Khazar Origin of Ancient Kiev", SEER 3/1 (1944): 108-124.

${ }^{52}$ Björn Ambrosiani de Kiev'i ele geçirme hedeflerinin Doğu Roma ve Abbâsîler ile doğrudan temas kurma isteğinden kaynaklandığını vurgular. Bkz. "Birka”, 130.
} 
meliklerinin ilki Dîr'dir (الدير).. Bundan sonra Sakālibe meliklerinden Ufrag (الأفرغ) gelir..." 53 Buradaki Dîr ile Povets Vremennih Let'te Kiev'in Rürik Hânedanı öncesi yöneticilerinden biri olarak betimlenen Dir'in (Диръ $)^{54}$ aynı kişiler oldukları açıktır. Mes'ûdî'nin Dîr'den sonraki Sakälibe hükümdarı olarak zikrettiği Ufrag da kolayca tahmin edileceği gibi, 882 yılında Dir'in elinden Kiev şehrini zorla almış olan Rürik'in halefi Knez Oleg (880-912) idi.55

Çizdiğimiz Erken Rus tarihinin çerçevesini doğrulayan çok önemli bir diğer pasaj da İstahrî tarafından miladî $X$. yüzyılın başlarına dair olarak aktarilır: 56

“Rûs'lar (الروس) üç sınıftır. Bir sınıfı Bulgār'a yakındır ve melikleri, Bulgār'dan daha büyük olan Kûyâbe (كُوَيَّبَ) [Kiev] denilen şehirde ikamet eder. Onlardan [Kiev'dekilerden] daha uzaktaki sınıf, Salâviyye [Novgorod'daki Sloveni] diye isimlendirilir. Diğer sinıfları Ersâniyye (الأرْثانَيَّة) diye isimlendirilir ve onların melikleri Birka'da ${ }^{57}$ oturur..."

Açıkça anlaşılacağı gibi, X. yüzyıl başlarında Birkalıların girişimleriyle güneye yönelen Rûs'ların Novgorod ve Kiev'e hâkim olmalarından bir şekilde Müslümanlar da haberdar olmuşlardı. Bu noktada István Vásary'nin, Müslüman coğrafya eserlerindeki bu türden bilgilerin bizzat Müslüman tüccarlarından kaynaklandığını ve bu nedenle kaynak değerlerinin oldukça yüksek olduğunu belirttiğini hatırlatmak gerekir. ${ }^{58}$ Nihayetinde Müslüman coğrafyacılarının Müslüman tüccarlarından elde ettikleri bu ve benzeri bilgiler neticesinde "Doğu'nun Vikingleri" diye adlandırdığımız Rûs'ların güneye yayılma tarihlerine dair çok önemli ayrıntılara vakıf olabildiğimiz ortadadir.

\footnotetext{
${ }^{53}$ Mes'ûdî, Mürûcü'z-zeheb, I, 324.

${ }^{54}$ Letopis Nestora, 10-11.

${ }_{55}$ Alexander A. Vasiliev de Mes'ûdî tarafından aktarılan haberdeki kişilerin gerçekten de Dir ve Oleg olduklarını düşünmektedir. Bkz. "The Second Russian Attack on Constantinople”, DOP 6 (1951): 178-179.

56 İstahrî, Kitâbü'l-Mesâlik ve'l-memâlik, 221. Biraz değiştirilmiş hâliyle ayn haber için bkz. İbn Havkal, Sûretü'l-arz, II, 397.

${ }^{57}$ Her ne kadar araştırmacılar, Jan Michael de Goeje tahkikinden dolayı bu şehrin adını Ersâ

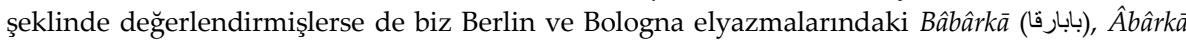

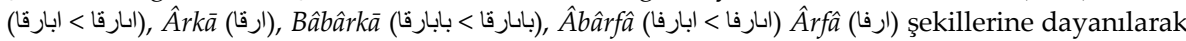
Birka şeklinde okunması gerektiği gösterilmişti. Bkz. Erman Şan, "İstahrî̀ye Göre "R̂िsların Ü̧ Sınıfı" ve Bunların Üç Şehrinin Yeniden Değerlendirilmesi: Kiev, Novgorod, Birka", TDA 112/221 (2016): 128. Konuya dair çalışmasında Peter B. Golden ise, "Rus Kağanlığı"nın İdil ve Oka Havzası'nda bulunmuş olabileceğini ve söz konusu R̂ิs'ların da İstahrî́nin pasajinda üçüncü sınıf olarak anlatılanlar olduğunu düşünmektedir. Bkz. "The Question of the Rus' Qağanate": 7797.

${ }^{58}$ István Vásary, Eski İç Asya'nın Tarihi, çev. İsmail Doğan (İstanbul: Ötüken Neşriyat, 2007), 227.
} 
Yayılmanın başlangıç anına dair olan ve Birka ile ilgisi bulunan ilk bilgiler ise, yazımızda da üzerinde durduğumuz İbn Rüste'nin er-R̂ิsiyye başlı̆̆ altında aktardığı ve Hâkānü Rûs'tan bahsettiği pasajda aktarılmıştır. Bu açıdan el-A 'lâku'n-nefîse' deki ilgili pasajın, Birka'nın Erken Viking Çağı'ndaki önemi, Viking Çağı'nın İskandinavları ve onların Avrupa'nın doğusuna doğru yayılan kolu olan R̂ेs'lar hususunda eşsiz bilgiler barındırdıklarını açıkça söyleyebiliriz.

\section{Sonuç}

Bu çalışmamızda İbn Rüste'nin el-A'lâku'n-nefisse isimli eserinde er-Rûsiyye başlığı altında Erken dönem Ruslarının yöneticilerinin kullandığı belirtilen ve tam olarak karşılığ 1 "Rus Hakanı" veya "Rus Kağanı" olan Hâkānü R̂̂s unvanını değerlendirildi. Ortaçağ İslâm coğrafyacılarının bazıları tarafından aktarılan benzer mahiyetteki başkaca bilgileri de göz önünde bulundurduğumuzda el-A'lâku'n-nefisse'de Hâkānü R̂̂s ile kastedilenin gerçekten de bir "Rus Kağanı" veya "Rus Hakanı" olduğunu görüldü. Her ne kadar bazı araştırmacılar Hazarlardan bir etkilenme veya bir yakıştırmayı söz konusu etmişlerse de, İbn Rüste'nin bahsettiği Hâkānü Rûs'un veya onun temsilcilerinin bu unvanı kullanmaktaki esas gerekçeleri, Hazarların uluslararası ticarette oynadıkları rolle ilgiliydi. Çünkü Hazarlar, İskandinavya gibi kuzey memleketlerinin değerli ürünlerinin güneydeki büyük ekonomiler Doğu Roma ve Abbâsîlere taşınması konusundaki en önemli aracılardı. Miladî VIII. yüzyıl sonunda gerçekleşen Hazar-Abbâsî barışının ardından bir ticarî çekim merkezi hâline gelen Hazar memleketine ürünlerini getirenler arasında, İbn Rüste'nin meliklerine hâkān denildiğini belirttiği R̂िs'lar da bulunuyordu. Bu unvanı kullanarak kendilerinin de Hazarlar gibi olduklarını vurgulamaya çalışırlarken; asıl istedikleriyse kendilerine de tıpkı Hazarlar gibi ticaret yapma imkânı tanınmasıydı.

İbn Rüste'nin pasajında bahsettiği dönem İskandinavya'sında Hâkānü Rûs'un hâkim olduğu adanın tarifine uyan sadece tek bir şehir olduğu da görülmüştür. Burası da Viking Çağı'nın ilk şehri olarak VIII. yüzyıl ortalarında kurulmuş olan Birka'ydı. Birka, tıpkı İbn Rüste'nin pasajındaki gibi Björkö adası üzerinde bulunuyordu. 865 yılındaki ölümüne değin misyonerlik faaliyetleri için 829-830 ve 851-852 yıllarında Birka'da bulunan Anskar'ın hayatının anlatıldığı Vita Anskarii'de, Birka'ya ilk gidişinde Biörn isimli, ikinci gidişinde de Olef isimli krallardan bahsedilmiş olması da bu şehirde İ̉bn Rüste'nin bahsettiği gibi bir "Hâkānü Rûs"un varlığını doğrular.

Anlaşıldığı kadarıyla güneyle ve bilhassa Müslümanlarla olan ticaret Birkalı Rûs'lar açısından oldukça kârlıydı. Vita Anskarii'de tam olarak ele 
aldığımız döneme dair, Birka'nın zengin tüccarlar, pek çok mal ve parayla dolu bir şehir olarak betimlenmesinde de bu ticaretin payı varmış gibidir. Belki de Hazarlar gibi aracılar olmasaydı daha da kârlı olabilirdi. IX. yüzyıl ortalarında Birka'nın yöneticileri de kendilerine bu soruyu sormuş olmalılar. Büyük ihtimalle güneydeki büyük ekonomiler olan Doğu Roma'ya ve Abbâsîlere, Hazarların yeniden ihracatı yerine kendilerinin doğrudan ihracatı teklifini götürmüşlerdi. Amaçları da bilhassa Hazarları saf dışı bırakmak ve daha fazla gümüş elde etmek olarak düşünülebilir. Bu Birkalı R̂̂s tüccarları veya elçileri de Doğu Roma ve bilhassa Müslümanlar nezdinde kendilerini tanıtmanın en kestirme yolu olarak tıpkı Hazarlar gibi kağana sahip bir kağanlık olduklarını belirtmiş olmalıdırlar. Kagan unvanının aslında augustus'un ve şehinşâh'ın bozkırdaki mukabili olduğu düşünülünce, buradaki asıl vurgunun çok da cihanşümullük kaygısı taşımadığı düşünülebilir. Yalnızca bir hükümdarları olduğunu ve tıpkı Hazarlarla yaptıkları gibi kendileriyle de doğrudan siyasî ve bilhassa da ticarî münasebetler kurabileceklerini vurgulamak istemiş olmalıdırlar. Özetle burada bir rol çalma girişimi söz konusudur. 


\section{Kaynakça}

Ahmad, Sayyid Maqbul. “íbn Hurdâzbih.” DİA. XX. 78-79.

Ahmetbeyoğlu, Ali. "Avrupa Hun ve Hazar Devletlerinin İktisadî Gelir Kaynaklar1." Belleten 69/254 (2005): 117-129.

Androshchuk, Fjodor. "Vikingler Doğuda." Viking Dünyası. ed. Stefan Brink Neil Price. çev. Ebru Kılıç. İstanbul: Alfa Yayıncılık, 2015, 653-684.

Ambrosiani, Björn. "Birka and Scandinavia's Trade with the East." Russian History 32/3-4 (2005): 287-296.

Ambrosiani, Björn. "Birka." Viking Dünyası. ed. Stefan Brink - Neil Price. çev. Ebru Kılıç. İstanbul: Alfa Yayıncılık, 2015, 125-132.

Annales Bertiniani. ed. Georg Waitz. Hannoverae 1883.

Artamonov, Mihail İ. Hazar Tarihi: Türkler, Yahudiler ve Ruslar. çev. D. Ahsen Batur. İstanbul: Selenge Yayınları, 2004.

Barnes, Michael P. “Viking Çağında İskandinav Dilleri.” Viking Dünyası. ed. Stefan Brink - Neil Price. çev. Ebru Kılıç. İstanbul: Alfa Yayıncılık, 2015, 343-352.

Brink, Stefan. “Vikingler Kimdi?” Viking Dünyası. ed. Stefan Brink - Neil Price. çev. Ebru Kılıç. İstanbul: Alfa Yayıncılık, 2015, 16-20.

Brink, Stefan. “İskandinavya'nın Hıristiyanlaşması ve İlk Kiliselerin Doğuşu." Viking Dünyası. ed. Stefan Brink - Neil Price. çev. Ebru Kılıç. İstanbul: Alfa Yayıncilık, 2015, 777-786.

Brutzkus, Julius. "The Khazar Origin of Ancient Kiev." The Slavonic and East European Review 3/1 (1944): 108-124.

Cross, Samuel H. "The Scandinavian Infiltration into Early Russia." Speculum 21/4 (1946): 505-514.

Dunlop, Douglas Morton. Hazar Yahudi Tarihi. çev. Zahide Ay. İstanbul: Selenge Yayınları, 2008.

Eberhard, Wolfram. "Bir Kaç Eski Türk Ünvanı Hakkında." Belleten 9/35 (1945): 319-340.

Ebû Ubeyd el-Bekrî. el-Mesâlik ve'l-memâlik, II. thk. Cemâl Tulbe. Beyrut 2003.

Ebû Yûsuf. Kitâbü'l-Harâc. çev. Ali Özek. İstanbul 1973.

Garipzanov, Ildar. "The Annals of St. Bertin (839) and Chacanus of the Rhos." Ruthenica 5 (2006): 7-11.

Golden, Peter B. Türk Halkları Tarihine Giriş. çev. Osman Karatay. İstanbul: Ötüken, 2017.

Golden, Peter B. "Rūs." EI². VIII. 618-623.

Golden, Peter B. "The Question of the Rus' Qağanate." Archivum Eurasiae Medii Aevi 2 (1982): 77-97. 
Golden, Peter B. Hazar Çalışmaları. çev. Egemen Ç. Mızrak. İstanbul: Selenge Yayınları, 2006.

Hedenstierna-Jonson, Charlotte. "Rus', Varangians and Birka Warriors." The Martial Society: Aspect of Warriors, Fortifications and Social Change in Scandinavia. ed. Lena Holmquist Olausson - Michael Olausson. Stockholm: Archaeological Research Laboratory, Stockholm University, 2009, 159-178. Hudûdü'l-âlem. Eng. trans. Vladimir F. Minorsky. London 1937.

Isitt, Guy F. "Vikings in the Persian Gulf." Journal of the Royal Asiatic Society 17/4 (2007): 389-406.

İbn Havkal. Sûretü'l-arz, II. ed. Johannes Heindrik Kramers. Lugduni Batavorum 1939.

İbn Hurdâzbih. Kitâbü'l-Mesâlik ve'l-memâlik. ed. Michael Jan de Goeje. Lugduni Batavorum 1889.

İbn Miskeveyh. Tecâribü'l-ümem ve te'âkibü'l-himem, III. thk. Seyyid Kesrevî Hasan. Beyrut 2003.

İbn Rüste. el-A'lâku'n-nefisse. thk. Halîl el-Mansûr. Beyrut 1998.

İstahrî. Kitâbü'l-Mesâlik ve'l-memâlik. ed. Michael Jan de Goeje. Lugduni Batavorum 1927.

Jackson, Tatjana N. "Aldeigjuborg of the Sagas in the Light of Archaeological Data." Á austrvega: Saga and East Scandinavia, I. ed. Agneta Ney - Henrik Williams - Fredrik C. Ljungqvist. Gävle: Gävle University, 2009, 438-442.

Kafesoğlu, İbrahim. Türk Millı̂ Kültürü. İstanbul: Ötüken Neşriyat, 2007.

Kisch, Bruno. "Weights and Scales in Mediaeval Scandinavia: A New Proof of Arabic Influence on Northern Europe in Viking Times." Journal of the History of Medicine and Allied Sciences 14/2 (1959): 160-168.

Kmosko, Michael. “Araplar ve Hazarlar.” çev. A. Cemal Köprülü. TM 3 (19261933): 133-155.

Kovalev, Roman K. - Alexis C. Kaelin. "Circulation of Arab Silver in Medieval Afro-Eurasia." History Compass 5/2 (2007): 560-580.

Kraçkovskiy, İgnatiy Yulianoviç. Arabskaya Geografiçeskaya Literatura. Moskva - Leningrad: İzdatelstvo Akademii Nauk SSSR, 1957.

Kurat, Akdes Nimet. Rusya Tarihi: Başlangıçtan 1917'ye Kadar. Ankara: TTK, 1999.

Letopis Nestora. ed. İ. Glazunova. Sankt Peterburg 1903.

Mallory, James P. Hint-Avrupalıların İzinde: Dil, Arkeoloji ve Mit. çev. Müfit Günay. Ankara: Dost Kitabevi, 2002.

Mes'ûdî. Mürûcü'z-zeheb, I. thk. 'Afîf Nâîf Hatum. Beyrut 2010.

Mikkelsen, Egil. “Vikingler ve İslam.” Viking Dünyası. ed. Stefan Brink - Neil Price. çev. Ebru Kılıç. İstanbul: Alfa Yayıncılık, 2015, 685-693. 
Pritsak, Omeljan. “The Origin of Rus'.” Russian Review 36/3 (1947): 249-273.

Montgomery, James E. “Arapça Kaynaklarda Vikingler." Viking Dünyası. ed. Stefan Brink - Neil Price. çev. Ebru Kılıç. İstanbul: Alfa Yayıncılık, 2015, 694-707.

Özcan, Altay Tayfun. “Karolenj Sarayındaki Rus Elçilerinin Kağanı: Rus Kağanı mı Hazar Kağanı mı?" (yakında çıkacak).

Pritsak, Omeljan. “Türk-Slav Ortak Yaşamı: Güneydoğu Avrupa'nın Türk Göçebeleri." çev. Osman Karatay. Türkler, II. ed. Hasan Celal Güzel Kemal Çiçek - Salim Koca. Ankara: Yeni Türkiye Yayınları, 2002, 509-520.

Rapoport, Semen. "Mohemmedan Writers on Slavs and Russians." The Slavonic and East European Review 8/22 (1929): 80-98.

Rimbert. Vita Anskarii. Eng. trans. Charles H. Robinson. 1921.

Ros, Jonas. "Sigtuna." Viking Dünyası. ed. Stefan Brink - Neil Price. çev. Ebru Kılıç. İstanbul: Alfa Yayınc1lık, 2015, 178-183.

Shepard, Jonathan. "Viking Rus ve Bizans." Viking Dünyası. ed. Stefan Brink Neil Price. çev. Ebru Kılıç. İstanbul: Alfa Yayıncılık, 2015, 626-652.

Sivrioğlu, Ulaş Töre. "8-11. Yüzyıllarda Müslüman - Viking Ticareti ve Kuzey Avrupa'da Bulunan İslâm Dirhemleri." Arkeoloji ve Sanat 155 (2017): 197214.

Skre, Dagfinn. "İskandinavya'da Kentleşmenin Gelişmesi." Viking Dünyası. ed. Stefan Brink - Neil Price. çev. Ebru Kılıç. İstanbul: Alfa Yayıncılık, 2015, 111-124.

Şan, Erman. "Mu'tasım-Billâh'ın 223/838 Yılındaki Asia Minor Seferinin Hedefi: Küçük Constantinopolis." Akdeniz Uygarlikları Araştırma Dergisi 8 (2020): 547-561.

Şan, Erman. "İbn Rüste'nin el-A'lâku'n-nefìse'yi Ne Zaman Yazdığına Dair Yeni Tespitler." Belleten 83/296 (2019): 65-88.

Şan, Erman. "Eski Ruslar ve Erken Tarihleri Bağlamında Köle İstihsâl Süreçleri Üzerine (IX.-X. Yüzylllar)." Tarihin Peşinde Bir Ömür Abdülkadir Özcan'a Armağan. ed. Hayrunnisa Alan - Ömer İşbilir - Zeynep Aycibin Muhammet Ali Kılıç. İstanbul: Kronik, 2018, 711-735.

Şan, Erman. "Besiûs el-Melik ve Sakālibe'nin Hıristiyan Olması (Basileus Symeon ve Tuna Bulgaryası'nın Hiristiyanlaşması)." Türk Dünyası Araştırmaları 114/224 (2016): 191-208.

Şan, Erman. "İstahrî̀ye Göre "R̂ิsların Üç Stmıfi" ve Bunların Üç Şehrinin Yeniden Değerlendirilmesi: Kiev, Novgorod, Birka." Türk Dünyası Araştırmaları 112/221 (2016): 117-134.

Şeşen, Ramazan. İslâm Coğrafyacılarına Göre Türkler ve Türk Ülkeleri. Ankara: TTK, 2001. 
Şeşen, Ramazan. Müslümanlarda Tarih-Coğrafya Yazıcılı̆̆ı. İstanbul: İSAR Vakfı Yayınları, 2016.

Taberî. Târîhu'l-ümem ve'l-mülûk, VIII. thk. Muhammed Ebü'l-Fazl İbrâhim. Kahire 1976.

Thomsen, Vilhelm Ludvig Peter. The Relations between Ancient Russia and Scandinavia and The Origin of the Russian State. Oxford - London: James Parker and Co., 1877.

Vásary, István. Eski İç Asya'nın Tarihi. çev. İsmail Doğan. İstanbul: Ötüken Neşriyat, 2007.

Vasiliev, Alexander A. "The Second Russian Attack on Constantinople."

Dumbarton Oaks Papers 6 (1951): 163-225. 